\title{
Transferable Competences and the Students' View of Their Significance and Satisfaction with Them: International Comparative Research
}

\author{
Lucie Smekalova $^{1, *}$, Jan-Willem Noom $^{2}$, Milan Slavik ${ }^{1}$ \\ ${ }^{1}$ Institute of Education and Communication, Czech University of Life Sciences Prague, Czech Republic \\ ${ }^{2}$ Stoas Wageningen, Vilentum University of Applied Science, Netherlands
}

Copyright $(\mathcal{C} 2016$ by authors, all rights reserved. Authors agree that this article remains permanently open access under the terms of the Creative Commons Attribution License 4.0 International License

\begin{abstract}
The paper presents the results of comparative research between the Czech Republic and the Netherlands. The subject of the research was the degree of student satisfaction with the acquired transferable competences and the subjective students' view of the degree to which transferable competences are significant for the employability of an individual at the job market. With the use of statistical methods (the Non-parametrical U-test of Mann and Whitney, the Chi-square Goodness-of-Fit Test), following conclusions are drawn. The empirical research has proved on the explored sample that: (1) there are significant differences between the respondents of both countries in the individual level of satisfaction with transferable competences; but (2) there are not significant differences between the transferable competences themselves of both countries expressing the level of students' satisfaction with them. Moreover, the research has proved that: (3) there are significant differences among the transferable competences themselves of both countries (CZ and NL) expressing the level of satisfaction that the students attribute to them; (4) in the Czech Republic, the following competences are perceived as absolutely necessary: communication in the mother tongue, work with digital technologies, sense of responsibility; whereas (5) in the Netherlands communication in the mother tongue is perceived as absolutely necessary and communication in foreign languages, sense of initiative and entrepreneurship, teamwork are viewed as important competences.
\end{abstract}

Keywords Transferable Competences, Satisfaction with Transferable Competences, Significance of Transferable Competences, Subjective View of the Students, Vocational Education, International Research, The Czech Republic (Hereinafter CZ), The Netherlands (Hereinafter NL).

\section{Introduction}

Social aspects are becoming more and more significant for economic environment. These social aspects include e.g. so-called corporate social responsibility which "is one of the useful tools to positively affect society and develop relationships with stakeholders" [1], or corporate education, also employment and employability. The employability is closely related to so-called transferable competences.

Transferable competences represent an attractive research area, both in academic discourse and in practice. The transformation of work environment (its conditions, requirements, technological advances) as well as the globalization of the job market stimulates the development of transferable competences. In this respect, demands are also placed on the educational environment (on graduates' qualification and competences).

The capabilities of individuals (graduates in this case) manifest themselves in the acquired level of gained competences. In our opinion, the level of gained competences and the degree of education do not correlate in the Czech educational environment. McClelland (1973) points out that the degree of education does not correspond to how successful one will be in future. Besides, employers need to know the answer to a question: "What should individual employees' competences be like so that the company is competitive?" [2]. In this context, we can ask a similar question: What should individual graduates' competences be like so that they are employable? The given issue is transferred from job market demands to a potential employee (a graduate) and through him to the professional training curriculum during the schooling. Therefore, another question arises: Is the university education of a given field beneficial for professional employability of graduates at the job market?

The term 'competences' itself is often used in the effort to describe to what extent the individuals have approached the requirements in different fields [3]. The required quality of activities expressed in competences is related to a professional standard set by the employers' sphere in order 
to define a standard qualification and standard performance [4]. The job market has showed that the term qualification is a static category (where a close relationship to the job performance is missing) and has started to work with competences as a dynamic category which is bound to professional situations [5].

In the past few years, there have been several surveys in the Czech Republic dedicated to transferable competences. For instance, Kozel and Vilamová [6] realized a survey of competence preferences from the employers' point of view. They evaluated the following competences as the most important: an active individual's attitude, the willingness to broaden one's knowledge, responsibility, motivation, work with PC and flexibility. They were least satisfied with the competences: language knowledge, work with people, field work and organization joint with management. Borůvková, Půlkrábková and Vaníček [7] monitor in their survey the benefit of bachelor studies for the further employment. There, the following competences are preferred: communication in mother tongue and foreign languages, the ability to decide and problem-solving. Krčmarská, Černý, Vaněk and Magnusková [8] present an interesting and inspiring survey from the mining industry and based on the survey they set the significance of individual competences in the mining industry practice. Other interesting foreign research in the field of transferable competences is represented by e.g. Frey, Balzer and Ruppert [9], OECD [10], Rocha [11], Yorke [12].

Authors of this paper consider the significance and satisfaction aspect related to transferable competences as important variables that can be researched in empirical surveys. However, we are interested in the view of vocational education students themselves and the possibility to compare these views on the international level.

\section{Objectives}

The objective of this empirical survey is to find out: (a) the subjective rate of the students' satisfaction with transferable competences, (b) the subjective students' view of the significance of transferable competences for the employability of an individual at the job market.

If the transferable competences are important for the employability of the students at the job market, then it is necessary to find out what level the students have acquired the particular transferable competences to (that is, how satisfied they are with their competences). At the same time, it is desirable to map what significance the students attach to these transferable competences.

The research results point out at its purpose and reveal: (a) the rate of mastering given competences (as a personal development and education results' index), (b) the direction of school curriculum development (for competences that prove insufficiently mastered; it is the study field evaluation index), (c) the reflection of competences' significance for the job market (as an index showing the motivation to study).

The research objectives reflect two research areas (that is: the satisfaction and significance in relation to transferable competences) and five research questions:

(a) for the area of satisfaction with transferable competences

(1) Are there any significant differences among the respondents of both countries ( $C Z$ and $N L)$ in the level of satisfaction with transferable competences?

(2) Are there any significant differences between the transferable competences of both countries (CZ and NL) expressing the level of students' satisfaction with them?

(b) for the area of significance of transferable

(3) Are there any significant differences among transferable competences in $C Z$ in terms of the significance level for the set categories of answers (absolutely essential, very important)?

(4) Are there any significant differences among transferable competences in NL in terms of the significance level for the set categories of answers (absolutely essential, very important, important)?

(5) Are there any significant differences between transferable competences themselves of both countries ( $\mathrm{CZ}$ and $N L$ ) expressing the significance level that the students attach to them?

The given issue is related to a target group of university students (future graduates) of fields focused on vocational education. The research results compare the current state of $\mathrm{CZ}$ and NL.

\section{Materials and Methods}

\subsection{Research Design}

This research is a quantitative empirical survey which verifies the null and the alternative hypothesis. Its statistical conclusiveness was verified by means of the Chi-square Goodness-of-Fit Test (in case of research question No. 3+4) and by means of the Non-parametrical U-test of Mann and Whitney (in case of research question No. 1,2 and 5). The data processing was done in MS Excel (in case of the Chi-square Goodness-of-Fit Test) on the basis of a statistical programme located on web pages (in case of the Non-parametrical U-test of Mann and Whitney, see research question No. 1), see the link [13] and also "in hand" according to a prescribed procedure for a very small scales of choices (in case of the U-test of Mann and Whitney, see research questions No. 2 and 5), see the link [14].

Two questionnaires were chosen as the data collection method; they contained items with the characteristics of transferable competences. The competences were chosen on the basis of the content analysis of information sources. The issue of choosing transferable competences was not an easy task. There are many lists of transferable competences supported with research findings, e.g. Allen [15], Gibbs, Rust, Jenkins and Jacques [16]; Karásek [17] etc. This research included those competences that appeared most 
frequently. Their characteristics was grounded in particular sources: item No. 1 - 5 [18], item No. 6 [19], item No. 7-8 [20]. The following transferable competences were chosen: (1) Communication in the mother tongue, (2) Communication in foreign languages, (3) Work with digital technologies, (4) Learning to learn, (5) Sense of initiative and entrepreneurship, (6) Problem solving, (7) Teamwork, (8) Sense of responsibility.

The responses to individual items (competences) are recorded on the Likert scale: (a) a numerical scale in the form of percentage (the satisfaction aspect), (b) a category scale (the significance aspect).

The research form was a short questionnaire including the questions about students' gender and age. The research sample was gained by a purposeful selection of last-year students. The questionnaires was distributed and processed in February 2015. Due to personal contacts of the research team members with target groups, the rate of return was $100 \%$. After data sorting, there were 58 valid questionnaires for the $\mathrm{CZ}$ and 68 questionnaires for the NL. The total number of respondents in both countries was 128 students. The criteria for eliminating a questionnaire were: (a) an incomplete filling-in, (b) illegibility of the answer marking.

\subsection{The Subject Matter of the Research}

The subject matter of the research is transferable competences. The term "transferable competences" is not defined unambiguously in the specialized discourse. It would be necessary to conduct its theoretical analysis, however, this is not the subject matter of the paper. Nonetheless, it is necessary to note that (1) the terms ability, skill and competence get confused, and (2) the attributes core, key, generic (or general) and transferable (or transversal) are used variously in relation to the given terms. Reflections on the characteristics of the terms or their differences can be found e.g. in: Stephenson [21], Connell, Scheridan and Gardner [22], Merriënboer, Van der Klink and Hendriks [23], Yorke [24], Dearing [25] etc. Therefore, different variations of these terms will occur in the paper due to the influence of the references to authors, e.g. generic/key/transferable skills or generic/key/transferable competences. The authors of the paper prefer the term transferable competences.

Transferable competences are "the generic capabilities which allow people to succeed in a wide range of different tasks and jobs" [26]. York [27] specifies that "the basic idea is that skills learned in one context could fairly readily be transferred to another". In other words, "transferable skills are important for individuals to enhance their employability, for employers to find qualified and able employees and for the economy that needs highly skilled workforce for economic growth and competitiveness" [28]. To become sustainable competent for functioning in the continuously changing labor market, a student has to develop metaskills and transferable competences [29].

In the given context, it is necessary to realize the difference that Strádal [30] points out: transferable competence is bound to more professions whereas professionally specific competence is bound to a particular profession. The subject matter of the research is transferable competences. Yorke [31] mentions that transferable competences "are attributes acquired in education and training that are not specific to the subject studied, but are skills and abilities that can assist students to enter the world of work or other activities". Therefore, they are applicable both in academic as well as professional situations [32, 33, $34,35]$.

In this context, the European Commission statement is considered significant [36]: „Universities have the potential to play a vital role in the Lisbon objective to equip Europe with the skills and competences necessary to succeed in a globalised, knowledge-based economy. In order to overcome persistent mismatches between graduate qualifications and the needs of the labour market, university programmes should be structured to enhance directly the employability of graduates and to offer broad support to the workforce more generally".

Subsequently, the adopted Recommendation of Education Council highlights the 'dual role' of education towards both 'social and economic' outcomes [37]. This leads to the development of even these key competences: Key Competences Cultural Awareness and Social and Civic Competence. European Commission [38] takes into account even the development of the key competences of disadvantaged students, namely it emphasizes the civic competence.

With regard to the research surveys done already, it can be claimed that in the field of vocational education (the field of study was forestry) 25 universities emphasized the competence learning to learn [39]. In the connection to the job market, such competences were researched that ensure the professional success of the graduates. On grounds of the research, it was proved that the Czech Republic is characterised by the lack of acquired competences elated to planning, co-ordinating and organising, applying rules and regulations and documenting ideas and information [40]. In the international research, a predominant approach was also identified for the key competences development [41]: (a) the competences are mostly developed through developing personal qualities in the Czech Republic, (b) the development of competences is based on Goals and Principles education in the Netherlands.

On a general level, the OECD project is beneficial (so called DeSeCo which provides a framework that can guide the longer-term extension of assessments into new competency domains [42].In our paper, the subjective view of vocational education students with regard to the significance of transferable competences and to the satisfaction with gained transferable competences is researched. The characteristics of particular transferable competences are described in chapter 3.4.

\subsection{The Respondents' Sample and Their Choice}

The research sample was gained by a purposeful selection of last-year students. The sample consists of the third-year 
students of the bachelor programme in the combined form of study at Institute of Education and Communication of the Czech University of Life Sciences Prague. The Dutch part is represented by the third- and fourth-year students of undergraduate and graduate programme in the daily and combined form at Stoas University of Applied Sciences.

The choice of these two institutions was based on the information about their curriculum: the curriculum of Stoas University of Applied Sciences has the form of an elaborate system of competences and the curriculum of the Institute of Education and Communication of the Czech University of Life Sciences Prague has the form of specific target requirements formed in the project Sirius. This project was focused on innovating the teaching in bachelor study programmes, which is on integrating new procedures, strategies, methodologies and organization forms of vocational education. The competence framework of Stoas is based on a national framework for teaching competences, designed by the Association of Professional quality Teachers (Stichting Beroepskwaliteit Leraren, (SBL) and leading to the principles in the Dutch law Professional in Education (Beroep in Onderwijs, BIO). Stoas has added some more competences based on entrepreneurship and research. Mittendorf and Kienhuis [43] defined a structure for guiding students in their professional development. It could be divided in three different elements: (1) Guidance in study progress: guiding the student through the study course, stimulating motivation and training transferable competences of skills; (2) Assistance with career development: counseling, reflection on professional tasks and responsibilities; (3) Assistance with professional development: development of a professional identity.

Inspiration was also found in Letschert's question [44]: „Are competence-driven curricula a better answer than, for example, the standards approach to the complexity of societal and personal demands, and how do school systems respond to these demands?" However, the authors of this paper are aware of the fact that other factors beside the curricula differences play its role, too. Primarily, the relationship between the curriculum and the results of satisfaction and the results of significance with transferable competences was not searched. This statement is a subject matter of discussion in the next part of the paper.

\subsection{The Description of Data Collection Methods}

Two questionnaires were chosen as a data collection method and they contained items with transferable competences characteristics. To be specific, eight transferable competences were chosen and researched. The respondents noted down their answers on a 5 -grade Likert scale.

The transferable competences have the following characteristics:

(1) Communication in the mother tongue: I am able to express and interpret concepts, thoughts, feelings, facts and opinions in both oral and written form (listening, speaking, reading and writing) and to interact creatively interact linguistically in an appropriate and creative way in a full range of societal and cultural contexts; in education and training, work, home and leisure.

(2) Communication in foreign languages: I am able to understand, express and interpret concepts, thoughts, feelings, facts and opinions in both oral and written form (listening, speaking, reading and writing) in an appropriate range of societal and cultural contexts (in education and training, work, home and leisure) according to one's wants or needs.

(3) Work with digital technologies: I can use ICT to retrieve, assess, store, produce, present and exchange information, and to communicate and participate in collaborative networks via the Internet.

(4) Learning to learn: I am able to organize my own learning, including through effective management of time and information, both individually and in groups. I am aware of my learning process and needs; I am able to identify available opportunities and to overcome obstacles in order to learn successfully. I am able to gain, process and assimilate new knowledge and skills as well as seeking and making use of guidance.

(5) Sense of initiative and entrepreneurship: I am able to be initiative, active and innovative. I. e. I am able to turn ideas into action based on creativity, ability to implement novelties, risk-taking, as well as ability to plan and manage projects in order to achieve objectives.

(6) Problem solving: I am able to identify and analyze the problem according to selected criteria, I am also able to produce a variety of alternative solutions to the problem, evaluate and choose the best possible solution, which I realize in practice.

(7) Teamwork: I am able to express my opinion, while respecting the views of the other members of the team, I can take into account others and create a compromise, I am able to adapt and do not enforce myself at the expense of others, I can share the experience and am capable to constructive criticism.

(8) Sense of responsibility: I am able to behave so that I can be relied on. When deciding, I am able to consider possible consequences of my actions. I can answer possible questions about my decision, i.e. I understand the causality of my behavior and possible consequences.

The respondents noted down their answers on a 5-grade Likert scale with percentage expression (in case of satisfaction aspect) in the following way: (1) $0-20 \%$, (2) $21-40 \%$, (3) $41-60 \%$, (4) $61-80 \%$, (5) $81-100 \%$. The responses were transformed in an ascending order to a point score that ranged from 1-5 points for each response. The respondents also noted down their answers on a 5-grade Likert scale expressed by categories (in case of significance aspect) in the following way: (1) less important, (2) important, (3) very important, (4) absolutely necessary.

\subsection{The Data Analysis Methods and the Processing Methodology}


The following tests were used for the statistical data processing with the significance level of 0.05: (a) the non-parametrical U-test of Mann and Whitney which verifies if two samples can come from the same basic set (in case of the research question No. 1, 2 and 5), (b) the Chi-square Goodness-of-Fit Test which verifies if the frequencies gained by measuring differ from theoretical frequencies expressed by the null hypothesis (in case of the research question No. 3 and 4).

In particular: the non-parametrical U-test of Mann and Whitney enabled a statistical processing with a significance level of 0.05 for frequencies $\mathrm{N}_{1}=58$ and $\mathrm{N}_{2}=68$ (see research question No.1) and for frequencies $\mathrm{N}_{1}=8$ and $\mathrm{N}_{2}=$ 8 (see research question No. 2 and No. 5).

Mann and Whitney's U-test for the research question No.1 was calculated on the basis of a statistical programme located on a website [45]. In this case, the test criterion for big groups (bigger than 20) has an approximately normal division. For the calculated standardized normal quantity, one seeks a figure attesting the distribution function and the density of probability of standardized normal division. On its basis, it is possible to interpret the significance test in such a way that if the calculated probability is smaller or equal to the chosen significance level, it is possible to reject the null hypothesis and accept an alternative hypothesis [46].

Mann and Whitney's U-test was processed for the research question No.2 and No. 5 manually according to the prescribed procedures for very little ranges of choice. This means that the measured figures from both samples are classified according to the size into a line. Every figure from the first sample is examined as to how many figures from the second sample precede it. The results of these findings are counted up and marked, and thus the test criterion for Mann and Whitney's U-test is reached. The interpretation of Mann and Whitney's significance test consists in the following rule [47]: if the calculated figure $U$ is lower or equal to the highly critical one, we reject the null hypothesis on the chosen significance level and we accept the alternative hypothesis.

The Chi-square Goodness-of-Fit Test was used to verify the research questions No. 3 and 4 in MS Excel. It worked with the significance level of 0.05 and seven grades of latitude, since there are eight transferable competences at our disposal $(\mathrm{N}=8)$. The calculated figure of the Chi-square test criterion is subsequently compared to the critical figure. The interpretation of the Chi-square Goodness-of-Fit Test is as follows [48]: If the calculated figure of the Chi-square test criterion is higher than the critical figure, we reject the null hypothesis and we accept the alternative hypothesis.
The data from the questionnaire (for the statistical processing of Mann and Whitney's U-test) were processed so that each grade of the response scale was attached with a point score. The double summarizing then made it possible to represent both the number of points for each respondent and the average number of points for each transferable competence. This way, it is possible to compare two groups of students, each of them representing their country, $\mathrm{CZ}$ and NL. Moreover, it is possible to compare the level of individual transferable competences among themselves again for both countries.

The data from the questionnaire (for the statistical processing of the Chi-square Goodness-of-Fit Test) were processed so that the observed frequencies for the set categories of responses were recorded to each competence ( less important, important, very important, absolutely necessary). Subsequently, each competence was highlighted in the response category in which it received the highest frequency. The aim was to find out if there is a statistical difference between the given competence (with the highest frequency) and the other competences in the given response category for each country (CZ and NL). In this way, we both examine the significance level of transferable competences among themselves in the given country and compare the significance level of transferable competences between the two countries.

\section{Results and Discussion}

The empirical research includes a research sample with the following average age of students: the Czech respondents are on average 5 years older (their average age is 33.5 years) than the Dutch respondents (the average age is 28.5 years). The age profile in relation to their experience may affect the research results, but a five-year interval may seem insignificant.

For the reasons of clarity, the research results with a discussion are presented in two separate chapters.

\subsection{The Students' View of the Satisfaction Level with Transferable Competences}

When comparing the average number of points reached by the men and the women in both countries, the results of respondents' satisfaction with transferable competences are similar (see Fig. 1). The women even reached the same point score (30.1), the men from CZ reached 0.2 more points $(31.4$ points) than the men from NL. 


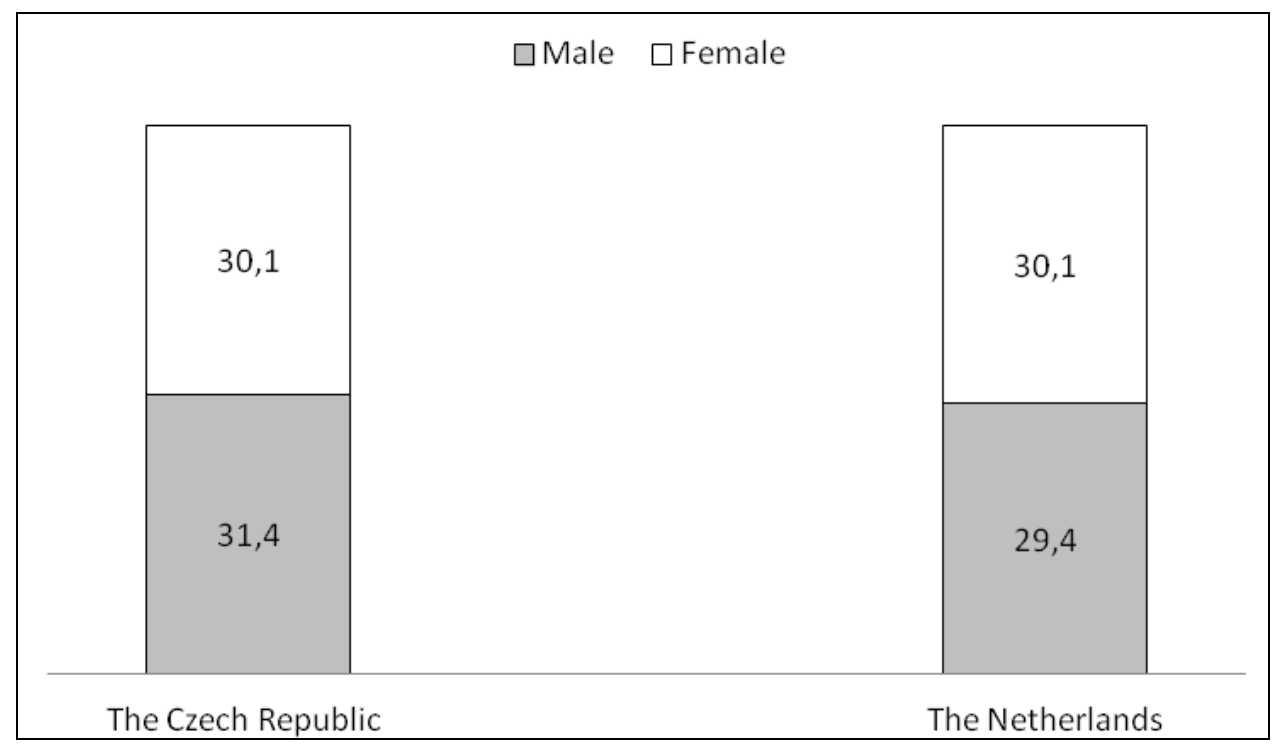

Figure 1. The average number of points of the men and women in both countries

Since the results create an average point evaluation, it is not possible to draw conclusions among individual respondents. Mann and Whitney's U-test will be used to assess the statistical significance of respondents' individual differences between the countries.

The research question No. 1 is explored: Are there any significant differences among the respondents of both countries (CZ and $N L)$ in the level of personal satisfaction with transferable competences? The verification is done on the basis of the hypotheses testing: (a) Null hypothesis: There are not statistically significant differences between respondents' results (expressed by a point score) of both countries; (b) Alternative hypothesis: There are statistically significant differences between respondents' results (expressed by a point score) of both countries.

By means of a statistical programme, a test criterion (the smaller one from the calculated figures) was calculated for the significance level $(0.05)$ and for frequencies $\left(\mathrm{N}_{1}=68\right.$ and $\mathrm{N}_{2}=58$ ), that is $\mathrm{U}=1528.5$ and subsequently a standardized normal quantity was calculated, that is $\mathrm{u}=-2.17$. There is a probability occurrence $\mathrm{u}=-2.17$ (the nearest table figure) $\varphi_{(-2,17)}=0.0440$ for the distribution function and for the probability density of a standardized normal distribution. The interpretation of the significance test is then the following: Since the probability $(0.0440)$ is smaller than the chosen significance level (0.05), we reject the null hypothesis and we accept the alternative hypothesis. That means that there are statistically significant differences between the respondents' results of both countries (expressed by a point score). Therefore, we can rightly argue that there are significant differences between Czech and
Dutch respondents in the individual level of satisfaction with transferable competences.

If the research results show that there are statistically significant differences between respondents of both countries, we are interested in whether it is also possible to trace statistically significant difference in the transferable competences themselves of both countries. The average point score for the researched transferable competences are presented in the graph below (see Fig. 2). It is evident that the students from $\mathrm{CZ}$ feel more satisfied with transferable competences than the students from NL. With regard to the competence "communication in foreign languages" only, the Dutch students reach up to 0.9 point higher satisfaction than Czech students.

The presented results give rise to a following reflection: are the respondents from $\mathrm{CZ}$ more self-confident, more competent or more experienced? The age might play its role, since Czech students are older than the Dutch ones. Another factor is the fact that the Czech students study in the combined form in contrast to the Dutch respondents' group that involves also students in the daily form of study. There is a higher probability of employment at the job market and related experience of students in the combined form rather than of students in the daily form of study.

Looking at the graph below (see Fig. 2), it is found out that the average point number is nearly comparable, with the exception of the competence "communication in foreign languages" and the competence "learning to learn". The interval reaches among the competences from $0.2-0.5$ point (the most frequent is the interval with a difference of 0.3 ). 


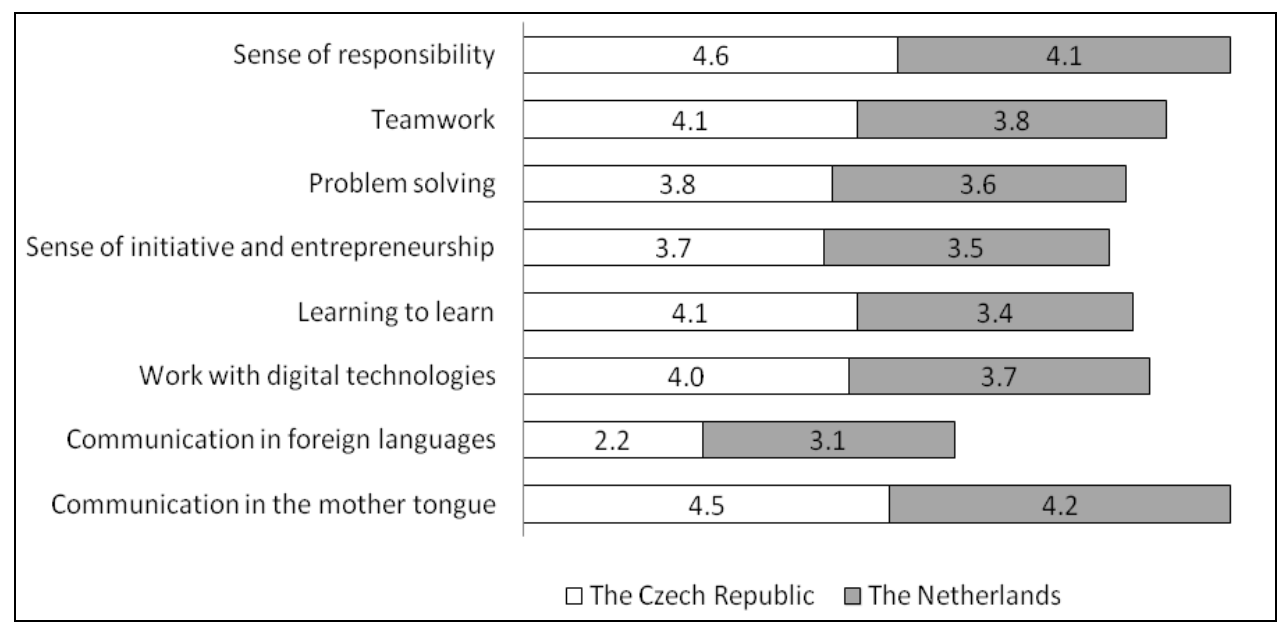

Figure 2. The average number of points for particular competences for both countries - the satisfaction aspect

Another factor might be the work with the curriculum at the given institution. For the empirical research, it was attractive to explore transferable competences at institutions that work with a given curriculum in a different way. However, the research was not primarily aimed at exploring the relationship between the work with the curriculum and the subjective level of satisfaction with transferable competences. Despite that, it is possible to substantiate the gained results hypothetically with reference to curricula. If the curriculum of Stoas University of Applied Sciences has the form of an elaborate system of competences, it is possible to presuppose that the students are used to working with the category of "competence". A competence is not static, but has several levels. One of the competence's attributes was proved here, i.e. that competences are developable [49]. In this context, the result of the Dutch respondents might be understandable because they can expect another level of development in the area of researched competences. It follows that their attitude, that is the subjective level of satisfaction with transferable competences does not reach the highest point score.

The curriculum of Institute of Education and Communication of the Czech University of Life Sciences Prague has the form of specific target requirements formed in the project Sirius. Therefore, it is possible to substantiate hypothetically that the students from $\mathrm{CZ}$ primarily know the category of "aims" including the requirement fulfilled vs. not fulfilled. On the basis of their subjective interpretation of the described researched transferable competences, the students respond in the framework of the requirement fulfilled vs. not fulfilled at the given competence as a whole. Therefore, it is assumed that the respondents concluded the satisfaction with transferable competences according to the range of listing of its content (i.e. quantitatively) rather than according to the level of saturation of the given listings of competence content (i.e. qualitatively). This fact of "the interpretation of the competences" might have caused certain coloring, which is some differences in results of both countries. Naturally, the personality of the respondents ought to be taken into account as well; they might have stylized the answers so as not to feel ashamed.

Although the discussion is varied, the conclusions are made on the basis of the collected data which are valid for the given sample of respondents and their statistical conclusiveness is verified. The research question No. 2 is explored: Are there any significant differences between the transferable competences of both countries (CZ and $N L$ ) expressing the level of students' satisfaction with them? The verification is done on the basis of hypotheses' testing: (a) Null hypothesis: There are not statistically significant differences between the results (point score averages) of the explored transferable competences in both countries; (b) Alternative hypothesis: There are statistically significant differences between the results (point score averages) of the explored transferable competences in both countries.

By means of a manual calculation according to the prescribed methodology [50], a test criterion (smaller from the two calculated figures) was calculated for the significance level (0.05) and for frequencies $\left(\mathrm{N}_{1}=8\right.$ a $\mathrm{N}_{2}=$ 8). It is $U=21$ that was compared to the critical figure which is $U_{(8,8)}=13$ for the given ranges. The interpretation of the significance test is then the following: since the calculated figure (21) is higher than the critical figure (13), we accept the null hypothesis. It can be rightly asserted that there are not significant differences between the transferable competences themselves of both countries ( $C Z$ and $N L$ ) expressing the level of students' satisfaction with them.

The stated conclusions prove that the data for both countries are comparable at the competence level (except competence learning to learn, see Tab. 1). It is only interesting to note that while the students from NL place communication in the mother tongue first and Sense of responsibility second, their Czech counterparts do it vice versa. 
Table 1. The order of transferable competences in both countries_the satisfaction aspect

\begin{tabular}{|c|c|c|c|c|}
\hline \multicolumn{2}{|c|}{ The Czech Rep. } & \multirow{2}{*}{$\begin{array}{c}\text { transferable competencies } \\
\text { - satisfaction - }\end{array}$} & \multicolumn{2}{|c|}{ The Netherlands } \\
\hline score & order & & order & score \\
\hline 4.5 & 2. & Communication in the mother tongue & 1. & 4.2 \\
\hline 2.2 & 8. & Communication in foreign languages & 8. & 3.1 \\
\hline 4.0 & 5. & Work with digital technologies & 4. & 3.7 \\
\hline 4.1 & $3 .-4$. & Learning to learn & 7. & 3.4 \\
\hline 3.7 & 7. & Sense of initiative and entrepreneurship & 6. & 3.5 \\
\hline 3.8 & 6. & Problem solving & 5. & 3.6 \\
\hline 4.1 & $3 .-4$. & Teamwork & 3. & 3.8 \\
\hline 4.6 & 1. & Sense of responsibility & 2. & 4.1 \\
\hline
\end{tabular}

Table 2. The distribution of frequencies among response categories_significance aspect_CZ

\begin{tabular}{|l|c|c|c|c|}
\hline \multicolumn{1}{|c|}{ Transferable competencies } & absolutely necessary & very important & important & less important \\
\hline 1_Communication in the mother tongue & 43 & 10 & 2 & 3 \\
\hline 2_Communication in foreign languages & 14 & 25 & 16 & 3 \\
\hline 3_Work with digital technologies & 29 & 18 & 8 & 3 \\
\hline 4_Learning to learn & 10 & 29 & 17 & 2 \\
\hline 5_Sense of initiative and entrepreneurship & 9 & 24 & 22 & 3 \\
\hline 6_Problem solving & 16 & 26 & 15 & 1 \\
\hline 7_Teamwork & 14 & 29 & 14 & 1 \\
\hline 8_Sense of responsibility & 33 & 21 & 2 & 2 \\
\hline
\end{tabular}

\subsection{The Students' View of the Significance Level with Transferable Competences}

The students' subjective view of the significance level of transferable competences which are important for an individual's employability at the job market is expressed in Tab. 2 (CZ) and Tab. 3 (NL). The respondents evaluated transferable competences in terms of significance rate (less important, important, very important, absolutely necessary). The highest frequency of a given response to every competence is marked in the tables.

The distribution of frequencies among response categories for particular competences in $\mathrm{CZ}$ is represented in Tab. 2 .

It is evident that the respondents consider as: (a) absolutely necessary the following competences: communication in the mother tongue, work with digital technologies, sense of responsibility, (b) very important the following competences: communication in foreign languages, learning to learn, sense of initiative and entrepreneurship, problem solving, teamwork. In the 'important' and 'less important' response categories, no competence got the highest frequency; therefore only 'absolutely necessary' and 'very important' response area will be statistically researched.

In particular, the research question No. 3 is examined: Are there any significant differences among the transferable competences in the Czech Republic with regard to the significance level for the set response categories (absolutely necessary' and 'very important)? The verification is done on the basis of testing the hypotheses No.1 and 2. Hypothesis No. 1: (a) null hypothesis: There are no statistically significant differences among transferable competences in the 'absolutely necessary' response category (expressed by frequencies); (b) alternative hypothesis: There are statistically significant differences among transferable competences in the 'absolutely necessary' response category (expressed by frequencies). Hypothesis No. 2: (a) null hypothesis: There are no statistically significant differences among transferable competences in the 'very important' response category (expressed by frequencies); (b) alternative hypothesis: There are statistically significant differences among transferable competences in the 'very important' response category (expressed by frequencies).

By means of the Chi-square Goodness-of-Fit Test, the test criterion of $\chi^{2}=51.42$ (for hypothesis No.1) and $\chi^{2}=12.42$ (for hypothesis No.2) was calculated for the significance level of 0.05 and 7 grades of latitude. The test criterion is compared to the critical figure which is $\chi^{2}{ }_{0.05}(7)=14.067$ for the given latitude grade. The results show that there are statistically significant differences among the transferable competences in the 'absolutely necessary' response category (see alternative hypothesis No.1). It follows that the differences are so considerable that they can be considered statistically significant. The stated competences (communication in the mother tongue, work with digital technologies, sense of responsibility) can be considered absolutely necessary compared to other competences. In contrast, the results in 'very important' response category did not prove statistically significant (see null hypothesis No.2), which means that the difference among competences is not so marked as to consider them very important. 
Table 3. The frequency distribution among response categories_significance aspect_NL

\begin{tabular}{|l|c|c|c|c|}
\hline \multicolumn{1}{|c|}{ Transferable competencies } & absolutely necessary & very important & important & less important \\
\hline 1_Communication in the mother tongue & 28 & 16 & 13 & 11 \\
\hline 2_Communication in foreign languages & 3 & 23 & 35 & 7 \\
\hline 3_Work with digital technologies & 9 & 27 & 26 & 6 \\
\hline 4_Learning to learn & 10 & 28 & 24 & 6 \\
\hline 5_Sense of initiative and entrepreneurship & 8 & 27 & 29 & 4 \\
\hline 6_Problem solving & 10 & 30 & 23 & 5 \\
\hline 7_Teamwork & 17 & 17 & 24 & 10 \\
\hline 8_Sense of responsibility & 14 & 34 & 13 & 7 \\
\hline
\end{tabular}

When looking at the frequency distribution among response categories for particular competences for the NL (see Tab. No. 3), we find out that no competence got the highest frequency in the less important' category, and therefore only 'absolutely necessary', 'very important' and 'important' response area will be researched. The respondents from NL consider as: (a) absolutely necessary the only competence: communication in the mother tongue, (b) very important the following competences: work with digital technologies, learning to learn, problem solving, sense of responsibility, (c) important the following competences: communication in foreign languages, sense of initiative and entrepreneurship, teamwork.

The research question No. 4 is examined: Are there any significant differences among transferable competences in $\mathrm{NL}$ in terms of the significance level for the set response categories (absolutely necessary, very important, important)? The verification is done on the basis of testing the hypotheses No.1 and 2 and 3. Hypothesis No. 1: (a) null hypothesis: There are no statistically significant differences among transferable competences in the 'absolutely necessary' response category (expressed by frequencies); (b) alternative hypothesis: There are statistically significant differences among transferable competences in the 'absolutely necessary' response category (expressed by frequencies). Hypothesis No. 2: (a) null hypothesis: There are no statistically significant differences among transferable competences in the 'very important' response category (expressed by frequencies); (b) alternative hypothesis: There are statistically significant differences among transferable competences in the 'very important' response category (expressed by frequencies). Hypothesis No. 3: (a) null hypothesis: There are no statistically significant differences among transferable competences in the 'important' response category (expressed by frequencies); (b) alternative hypothesis: There are statistically significant differences among transferable competences in the 'important' response category (expressed by frequencies).

By means of the Chi-square Goodness-of-Fit Test, the test criterion of $\chi^{2}=32.12$ (for hypothesis No.1) and $\chi^{2}=10.72$ (for hypothesis No. 2) and $\chi^{2}=17.32$ (for hypothesis No. 3) was calculated for the significance level of 0.05 and 7 grades of latitude. The test criterion is compared to the critical figure which is $\chi^{2}{ }_{0.05}(7)=14.067$ for the given latitude grade. The results show that there are statistically significant differences among the transferable competences in the 'absolutely necessary' response category (see alternative hypothesis No.1). It follows that the differences are so considerable that they can be considered statistically significant. The stated competence of communication in the mother tongue can be considered absolutely necessary compared to other competences. In contrast, the results in 'very important' response category did not prove statistically significant (see null hypothesis No. 2), which means that the difference among competences (work with digital technologies, learning to learn, problem solving, sense of responsibility) is not so marked as to consider them very important. There are statistically significant differences among the transferable competences in the 'important' response category (see alternative hypothesis No. 3), therefore these competences (communication in foreign languages, sense of initiative and entrepreneurship, teamwork) can be considered important compared to the other ones.

It is of interest that with regard to the students in CZ, only the competences from 'absolutely necessary' and 'very important' response categories gained the highest frequency in terms of significance. With regard to the students in NL, there is a category more, which is the 'important' response category. Why is it so? Is the concept of transferable competences so important for Czech students? Or is the situation at the job market in $\mathrm{CZ}$ perceived by them so dismal (high unemployment) that they evaluate these competences with a high rate of significance?

The Dutch students consider the competences of communication in foreign languages, sense of initiative and entrepreneurship and teamwork as important only. Are these competences so internalized that they do not evaluate them with a higher rate of significance? Does the curriculum type of education account for it? Apparently, the students are used more to working in teams, they develop the entrepreneurship within professionally oriented situations and they can speak more foreign languages. That is probably why other competences are evaluated better that the ones mentioned above.

The Table No. 4 presents a comparison of both countries ( $\mathrm{CZ}$ and NL) according to the criterion of the highest gained frequency with respect to significance within the categories of offered responses. 
Table 4. The competences with the highest frequency in the given response category for both countries_significance aspect

\begin{tabular}{|l|c|c|}
\hline \multicolumn{1}{|c|}{ transferable competencies } & The Czech Republic & The Netherlands \\
\cline { 2 - 3 } & response category & response category \\
\hline 1_Communication in the mother tongue & absolutely necessary & absolutely necessary \\
\hline 2_Communication in foreign languages & very important & important \\
\hline 3_Work with digital technologies & absolutely necessary & very important \\
\hline 4_Learning to learn & very important & very important \\
\hline 5_Sense of initiative and entrepreneurship & very important & important \\
\hline 6_Problem solving & very important & very important \\
\hline 7_Teamwork & very important & important \\
\hline 8_Sense of responsibility & absolutely necessary & very important \\
\hline
\end{tabular}

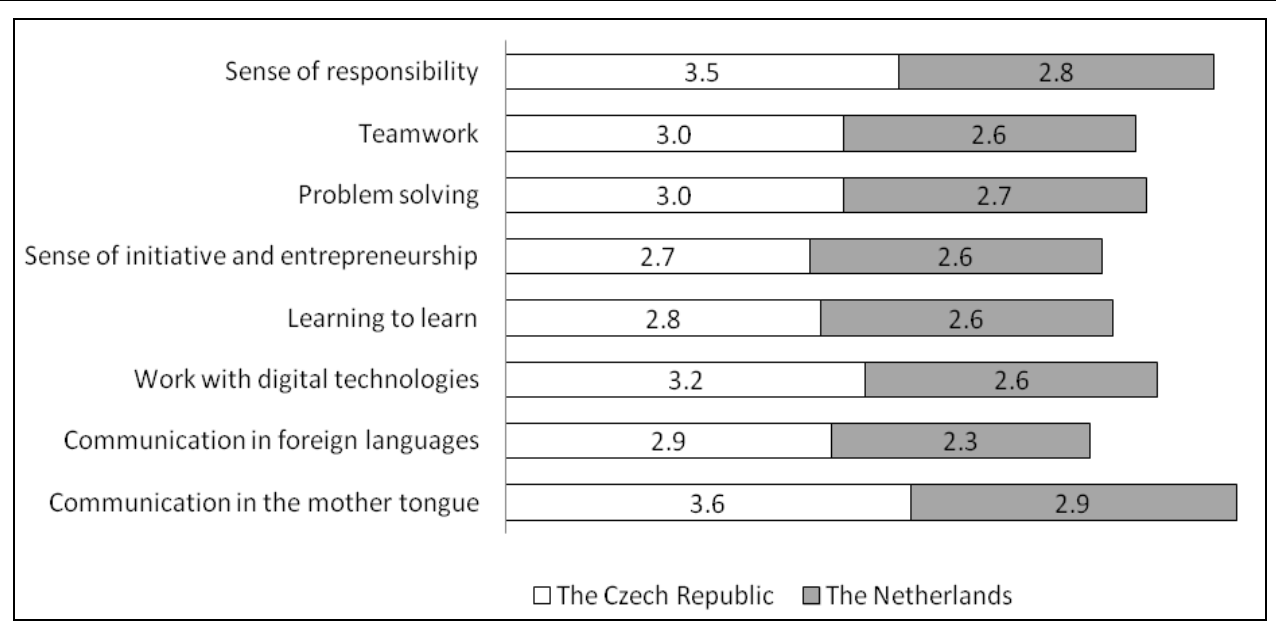

Figure 3. The average number of points for particular competences for both countries_significance aspect

We can see that students from both countries (CZ and NL) reached an agreement on considering communication in the mother tongue as an absolutely necessary competence and learning to learn and problem solving competences as very important. Moreover, students in $\mathrm{CZ}$ consider absolutely necessary even work with digital technologies and sense of responsibility most probably because getting a job in $\mathrm{CZ}$ is more often conditioned by work with digital technologies than by communication in foreign languages. This fact is derived from a survey that was realized by Kalenda and Surý [51] who examined the language competence level of employees in $\mathrm{CZ}$ who were applying for job positions in two thousand companies. The results of the sample showed that some job areas and work positions require mastering English as absolutely necessary while the Czech job market on the whole has not yet been substantially internationalized and mastering English is not the key factor of employability.

Due to the differences in evaluating the significance level of competences, the research question No.5 also proves advantageous: Are there any significant differences among the transferable competences themselves of both countries ( $C Z$ and $N L$ ) expressing the rate of significance that the students attach to them? Here we do not work with frequencies, but with the average point score for each competences that the respondents evaluated. The responses were multiplied according to an algorithm: (a) less important
(1 point), (b) important ( 2 points), (c) very important (3 points), (d) absolutely necessary (4 points). The graph (see Fig. 3) presents the average point score for the researched transferable competences.

It is evident that the respondents from $\mathrm{CZ}$ evaluate the given competences with a higher rate of significance than the students from NL. An exception to this result is represented only by the proximity of evaluating the competences: problem solving, sense of initiative and entrepreneurship, learning to learn.

The statistical conclusiveness is tested by means of Mann and Whitney's U-test. The verification is done on the basis of testing the hypotheses: (a) null hypothesis: there are no statistically significant differences between the results (averages of the point score) of the researched transferable competences in both countries; alternative hypothesis: there are statistically significant differences between the results (averages of the point score) of the researched transferable competences in both countries.

By means of a manual calculation according to the prescribed methodology [52], a test criterion (smaller from the two calculated figures) was calculated for the significance level (0.05) and for frequencies $\left(\mathrm{N}_{1}=8\right.$ a N $\left.\mathrm{N}_{2}=8\right)$. It is $U=6$ that was compared to the critical figure which is $\mathrm{U}_{(8,8)}=13$ for the given ranges. 
Table 5. The order of transferable competences in both countries_significance aspect

\begin{tabular}{|c|c|c|c|c|}
\hline \multicolumn{2}{|c|}{ The Czech Rep. } & transferable competencies significance & \multicolumn{2}{|c|}{ The Netherlands } \\
\hline 3.6 & 1. & Communication in the mother tongue & 1. & 2.9 \\
\hline 2.9 & 6. & Communication in foreign languages & 8. & 2.3 \\
\hline 3.3 & 3. & Work with digital technologies & 4.-7. & 2.6 \\
\hline 2.7 & 8. & Sense of initiative and entrepreneurship & 4.-7. & 2.6 \\
\hline 3.0 & 4.-5. & Problem solving & 3. & 2.7 \\
\hline 3.0 & $4 .-5$ & Teamwork & 4.-7. & 2.6 \\
\hline
\end{tabular}

The interpretation of the significance test is as follows: since the calculated figure (6) is smaller than the critical figure (13), we accept the alternative hypothesis. Therefore, we can rightfully claim that there are significant differences among the transferable competences themselves of both countries (CZ and NL) expressing the rate of significance that the students attach to them.

The stated conclusions confirm that the data for both countries are not comparable in terms of the significance level of transferable competences, which is also proved by the compared competence order between the countries, see Tab. 5 .

There is an exception in the same order of 'communication in the mother tongue' and 'sense of responsibility' being first and second respectively. The smallest rate of significance in $\mathrm{CZ}$ is attached to sense of initiative and entrepreneurship competence. Apparently, cultural differences account for this result with the Czech society not having been exposed to the enterprise sector for a long time. Another reason might be the mistrust of the Czech students in their own abilities and/or the feeling that as new employees, they must submit more to employer's interests. This fact has not proved in the results of the Dutch students who evaluated this competence more positively. What is more, the problem solving competence occupies the third position of significance in their evaluation; it is typical for the individual's employability at the job market due to the changing market and the need to adapt to quick changes. The Dutch students evaluated 'communication in foreign languages' as the least significant competence. This may be explained by their language capabilities (English, German, French) that has already been mentioned above.

\section{Conclusions}

The empirical research has proved on the explored sample that: (1) there are significant differences between the respondents of both countries in the individual level of satisfaction with transferable competences; but (2) there are not significant differences between the transferable competences themselves of both countries expressing the level of students' satisfaction with them. At the same time, the students from the Czech Republic are more satisfied with the transferable competences than the students from the Netherlands.

The research has also proved that: (3) there are significant differences among transferable competences in $\mathrm{CZ}$ in terms of significance level for the response category of absolutely necessary (i.e. communication in the mother tongue, work with digital technologies, sense of responsibility), however, there are no statistically significant differences for the "very important' response category; (4) there are significant differences among transferable competences in NL in terms of significance level for the response category of absolutely necessary (i.e. communication in the mother tongue) and for the 'important' response category (i.e. communication in foreign languages, sense of initiative and entrepreneurship, teamwork), but there are no statistically significant differences for the 'very important' response category (i.e. work with digital technologies, learning to learn, problem solving, sense of responsibility); (5) there are significant differences among the transferable competences themselves of both countries (CZ and NL) expressing the rate of significance attached to them by the students.

\section{Acknowledgements}

The paper was written in cooperation between Stoas University of Applied Sciences and Institute of Education and Communication of the Czech University of Life Sciences Prague. Stoas is a faculty of Vilentum University of Applied Sciences, one of the Aeres Group institutions. Since its foundation in 1981, Stoas has trained educators for 'land-based' subjects in environmental vocational education. Various programmes have been added since 2009. Naturally, this is linked to the professionalization of everyone professionally involved with learning and development. This core task is expanded through practical research in the field of teaching for vocational education and business. Logically, Stoas has many connections with other schools, universities, businesses, and research institutions, both on a national and international level. 


\section{REFERENCES}

[1] L. Kvasničková Stanislavská, R. Kvasnička, K. Kuralová, K. Margarisová. Social Responsibility of Higher Educational Institutions - the Comparison of the View of Students and Potential Students', Journal on Efficiency and Responsibility in Education and Science, Vol. 7, No. 3-4, 95-99, 2014.

[2] L. Krčmarská, I. Černý, M. Vaněk, J. Magnusková. Kompetenční model pro studenty Hornicko-geologické fakulty Vysoké školy báňské-Technické univerzity Ostrava z pohledu těžebních společností, Aula: časopis pro vysokoškolskou a vědní politiku, Vol. XXII, No. 1, 7-23, 2014.

[3] E. Klieme, K. Maag-Mergi, J. Hartig. Kompetence a jejich význam ve vzdělávání, Pedagogická orientace, Vol. 20, No. 1, 104-119, 2010.

[4] J. Vašutová. Profese učitele v českém vzdělávacím kontextu, Paido, Brno, 2004.

[5] Profesionalizace, Online available from http://www.nuv.cz/uploads/Periodika/ZPRAVODAJ/2000/Z P0010a.pdf

[6] R. Kozel, Š. Vilamová. Národní výzkum uplatnění absolventů vysokých škol na trhu práce, Kompetence absolventů vysokých škol: mezinárodní konference, VŠB-TU, Ostrava, 29-31, 2006.

[7] J. Borůvková, E. Půlkrábková, J. Vaníček. Uplatnění studentů bakalářského studijního programu, Kompetence absolventů vysokých škol: mezinárodní konference, VŠB-TU, Ostrava, 6-10, 2006.

[8] L. Krčmarská, I. Černý, M. Vaněk, J. Magnusková. Kompetenční model pro studenty Hornicko-geologické fakulty Vysoké školy báňské-Technické univerzity Ostrava z pohledu těžebních společností, Aula: časopis pro vysokoškolskou a vědní politiku, Vol. XXII, No. 1, 7-23, 2014.

[9] A. Frey, L. Balzer, J. Ruppert. Transferable competences of young people with a high dropout risk in vocational training in Germany, International Journal for Educational and Vocational Guidance, Vol. 14, No. 1, 119-134, 2014.

[10] OECD. Transferable skills training for researchers: Supporting career development and research, Organization for Economic Cooperation and Development, Paris, 2012.

[11] M. Rocha. Predictors of the acquisition and portability of transferable skills: a longitudinal Portuguese case study on education, Higher Eduacation, Vol. 69, No. 4, 607-624, 2014.

[12] M. Yorke. Grading student achievement in higher education: Signals and shortcomings, Routledge, Abingdon, 2008.

[13] U-test, Online available from http://faculty.vassar.edu/lowry/utest.html

[14] M. Chráska. Metody pedagogického výzkumu, Grada, Praha, 2007.

[15] M. Allen. A Conceptual Model of Transferable Personal Skills, Employment Department, Sheffield, 1993.
[16] G. Gibbs, C. Rust, A. Jenkins, D. Jacques. , Developing Students' Transferable Skills, Oxford Centre for Staff Development, Oxford, 1994.

[17] Z. Karásek. IPN KVALITA, Online available from http://kvalita.reformy-msmt.cz/rozvoj-mekkych-obecnych-k ompetenci-v-prubehu-studia-vs-soubor

[18] The European Framework for Key Competences for Lifelong Learning, Official Journal of the European Union, L 394, 2006.

[19] O. Šuleř. Manažerské techniky II., Rubico, Olomouc, 2003.

[20] S. Mühleisen, N. Oberhuber. Komunikační a jiné měkké dovednosti, Grada, Praha, 2008.

[21] J. Stephenson. The concept of capability and its importance in higher education, in J. Stephenson, M. Yorke (eds.), Capability and quality in higher education, Kogan Page, London, 1-13, 1998.

[22] M. W. Connell, K. Sheridan, H. Gardner. On abilities and domains, in J. R. Sternberg, E. L. Grigorenko (Eds.), The psychology of abilities, competencies and expertise, Cambridge University Press, Cambridge, 126-155, 2003.

[23] J. J. G van. Merriënboer, M. R. Van der Klink, M. Hendriks, M. Competenties: van complicaties tot compromis, Onderwijsraad, Den Haag, 2002.

[24] M. Yorke. Employability in higher education: What it is - what it is not, The Higher Education Academy, York, 2006.

[25] R. Dearing. Review of qualifications for 16-19 year olds [Full Report], School Curriculum and Assessment Authority, London, 1996.

[26] Training Agency. Enterprise in Higher Education: key features of Enterprise in Higher Education proposals, Training Agency, Sheffield, 1990.

[27] M. Yorke. Employability in higher education: What it is - what it is not, The Higher Education Academy, York, 2006 .

[28] A. Ylonen. Student ambassador experience in higher education: skills and competencies for the future?, British Educational Research Journal, Vol. 38, No. 5, 801-811, 2012.

[29] M. Kuijpers, F. Meijers. Studieloopbaanbegeleiding in het hbo: mogelijkheden en grenzen, Haagse Hogeschool, Den Haag, 2009.

[30] J. Strádal. Tvoříme firemní kompetenční model, Online available from

http://www.profesnisachovnice.cz/tvorime_firemni_kompete ncni_model.pdf

[31] A. Ylonen. Student ambassador experience in higher education: skills and competencies for the future?, British Educational Research Journal, Vol. 38, No. 5, 801-811, 2012.

[32] N. Blagg, M. Ballinger, R. Lewis. The Development of Transferable Skills in Learners, Employment Department, Sheffield, 1993.

[33] D. Bridges. Transferable skills: A philosophical perspective, Studies in Higher Education, Vol. 18, No. 1, 43-51, 1992.

[34] D. Chadra. A curriculum model for transferable skills 
development, Engineering Education, Vol. 1, No. 1, 19-24, 2006.

[35] G. Gibbs, C. Rust, A. Jenkins, D. Jacques. , Developing Students' Transferable Skills, Oxford Centre for Staff Development, Oxford, 1994.

[36] European Commission. Delivering on the modernisation agenda for universities: education, research and innovation, Communication from the Commission to the Council and the European Parliament, Brussels, 2006.

[37] Education Council. Recommendation of the European Parliament and the Council of 18 December 2006 on Key Competencies for Lifelong Learning, Official Journal of the European Union, Brussels, 2006.

[38] European Commission. Cluster Key Competences curriculum reform work priorities, European Commission, Brussels: 2006

[39] J. Arevalo, S Pitkänen, D. Gritten, L. Tahvanainen. Monetary Rewards and Competences of Young European Graduates, International Forestry Review, Vol. 12, No. 3, 200-208, 2010.

[40] J.-G. Mora, A. Garcia-Aracil, J.-M. Carot, L.E Vila. Monetary Rewards and Competences of Young European Graduates, in OECD, Higher Education Management and Policy, Vol. 18, No. 1, 37-50, 2006.

[41] G. Halász, A. Michel. Key Competences in Europe: interpretation, policy formulation and implementation, European Journal of Education, Vol. 46, No. 3, 289-306, 2011.
[42] OECD. Defining and Selecting Key Competences, OECD, Paris, 2001

[43] K. Mittendorff, M. Kienhuis. Studieloopbaanbegeleiding. Van visie naar praktijk, een handreiking, Saxion Hogescholen, Deventer, 2014.

[44] J. Letschert. Introduction, in J. Letschert, J. Bronn, H. Hooghoff (eds.), The integrated person: How curriculum development relates to new competencies, CIDREE/SLO, Enschede, 7-23, 2004.

[45] U-test, Online available from http://faculty.vassar.edu/lowry/utest.html

[46] M. Chráska. Metody pedagogického výzkumu, Grada, Praha, 2007.

[47] M. Chráska. Metody pedagogického výzkumu, Grada, Praha, 2007.

[48] M. Chráska. Metody pedagogického výzkumu, Grada, Praha, 2007.

[49] M. Slavík, R. Dytrtová, M, Hanušová, J. Husa, B. Krahulcová, D. Kučírková, D. Linhartová, I. Miller, D. Oudová, J. Votava. Vysokoškolská pedagogika, Grada, Praha, 2012.

[50] M. Chráska. Metody pedagogického výzkumu, Grada, Praha, 2007.

[51] J. Kalenda, D. Surý. Úloha jazykové vybavenosti při výběru zaměstnanců v ČR, Andragogika, Vol. 16, No. 2, 10-16, 2013.

[52] M. Chráska. Metody pedagogického výzkumu, Grada, Praha, 2007. 